Ніна Лавриненко, кандидат фізико-математичних наук, доцент, ORCID ID 0000-0002-2537-1110

Світлана Лисенко, кандидат педагогічних наук

ORCID ID 0000-0001-9651-6500

Воєнно-дипломатична академія імені Євгенія Березняка

\title{
ІННОВАЦІЙНИЙ ПІДХІД ДО СПЕЦІАЛЬНОЇ ІНШОМОВНОЇ ПІДГОТОВКИ МАГІСТРІВ ВІЙСЬКОВОГО УПРАВЛІННЯ В МІЖНАРОДНИХ ВІДНОСИНАХ
}

Розглянуто один із засобів формування інтегративних компетениій, який полягає в поєднанні методик психофізіологічної саморегуляиії функиіональних станів майбутніх магістрів військового управління в міжнародних відносинах з методиками іншомовної та фахової підготовки. Складено та апробовано номенклатуру загальних, інноваційних $i$ спеціальних методик психофізіологічної саморегуляції функціональних станів майбутніх магістрів військового управління в міжнародних відносинах. Інтенсифіковано прочес розуміння $і$ засвоєння майбутніми магістрами військового управління в міжнародних відносинах інтегративних компетенцій, а також створено передумови для формування та розвитку оптимального рівня мотивачії до вивчення іноземних мов.

Ключові слова: спеціальна іншомовна підготовка; інноваційний підхід; інтегративні компетенції; технології інтегрованого навчання; психофізіологічна саморегулящія; магістр військового управління в міжнародних відносинах.

Постановка проблеми. Участь України у міжнародних і міждержавних організаціях, підвищення рівня співробітництва, розширення договірної бази та іншомовної комунікації поставило перед закладами вищої освіти України завдання 3 підготовки конкурентноспроможних компетентних фахівців шляхом осучаснення навчальних програм і методик викладання іноземних мов [2]. Пошук ефективних педагогічно-психологічних технологій у контексті інтенсифікації вивчення іноземних мов має бути пов'язаний із застосуванням їхніми презентерами технології інтегрованого навчання, а також урахування того, що на розвиток іншомовної освіти впливають процеси глобалізації. Відповідно до Національної доктрини розвитку освіти України у XXI ст. пріоритетною складовою державної політики стає транзитивність наявної моделі підготовки професіоналів різної специфікації до особистісно орієнтованої. Сучасний професіонал, такий, як магістр військового управління в міжнародних відносинах (МВУМВ) - це сукупність якісних i квантитативних характеристик особистісно-адаптаційного потенціалу особистості, необхідного йому для ефективного виконання поставлених завдань в екстремальних умовах $[1 ; 3 ; 5 ; 8]$. У цьому контексті майбутні МВУМВ повинні мати супремальний рівень фахової іншомовної компетентності (ІМК), формування якої здійснюється в ході спеціальної іншомовної підготовки (СІмП) у Воєнно-дипломатичній академії імені Євгенія Березняка (ВДА). Специфіка цієї підготовки полягає в тому, що, поперше, ВДА немовна за профілем академія-атрактор, де враховується, що до 
МВУМВ висуваються нетривіальні вимоги щодо володіння ними іноземними мовами. По-друге, суб'єктами освітнього процесу є дорослі люди, спеціальна іншомовна підготовка яких передбачає врахування: індивідуальнопсихологічних особливостей і закономірностей розвитку дорослих осіб; обмеженості терміну вивчення іноземних мов; відсутності реального іншомовного середовища, обмежені можливості спілкування з носіями мови та можливість створення лише квазіпрофесійних ситуацій. По-третє, професійна діяльність МВУМВ відбувається у психологічно та психофізіологічно напружених умовах, що неодмінно потребує інтегративних компетенцій.

Отже, у сучасних умовах одним з актуальних завдань ВДА $є$ підготовка конкурентоспроможних МВУМВ із супремальним рівнем IMК у взаємозв'язку 3 високим рівнем психофізіологічної саморегуляції функціонального стану (ПФС) для ефективних дій в екстремальних умовах іншомовного середовища. Це у свою чергу зумовлює актуальність інноваційних підходів до їхньої СІмП, де ефективним засобом формування інтегративних компетенцій $\epsilon$ встановлення міжпредметних зв'язків, які полягають у поєднанні методик ПФС з матеріалом занять з іноземної мови та елементами майбутньої професійної діяльності, що в сукупності сприяє глибшому сприйманню та осмисленню виучуваної мови та паралельно дає можливість сформувати у майбутніх МВУМВ необхідний під час іншомовної комунікації рівень стресостійкості $[5,7,8]$.

Аналіз останніх досліджень і публікацій. Аналіз наукових джерел свідчить про те, що хоча проблеми вдосконалення іншомовної підготовки фахівців різного професійного спрямування досліджували І. Бім, О. Бодальов, І. Гончаренко, Г. Закіров, І. Зимня, В. Кальниш, А. Кирда, Н. Кузьміна, Н. Мальцева, Т. Максимова, О. Мельничук та інші, проте залишаються нерозв'язаними такі важливі проблеми, як врахування особливостей використання іноземної мови в умовах підвищеної психоемоційної напруженості, пов'язаної зі складністю й обсягом професійних завдань, дефіцитом часу на їх виконання, стресорами різної етимології тощо. У цьому контексті найбільш актуальним для формування ІМК супремального рівня є цілеспрямоване використання на заняттях 3 іноземної мови елементів психологічної підготовки.

Метою статті $\epsilon$ обгрунтування ефективності педагогічно-психологічних технологій для інтенсифікації вивчення іноземної мови у ВДА з урахуванням умов професійної діяльності МВУМВ та сучасних інтеграційних процесів.

Методи дослідження: теоретичні - для визначення мети, предмета, гіпотези i завдань дослідження; емпіричні (анкетування, тестування, самооцінювання) для з'ясування ставлення МВУ до використання методик ПФС у ході їхньої іншомовної підготовки та висновків експертів щодо фактичного рівня розвиненості іншомовних здатностей і саморегуляційних можливостей слухачів, прогностичні (метод експертних оцінок, анкетування та тестування) - для визначення рівнів розвиненості цих характеристик; 
методи математичної статистики - ранжирування для статистичного обгрунтування отриманих результатів, критерій Манна-Уїтні для оцінювання розбіжностей між двома вибірками, порівняння і статистичний аналіз для наукового узагальнення та інтерпретації експериментальних даних дослідження.

Виклад основного матеріалу. Професійна діяльність МВУМВ характеризується такими основними чинниками: інтенсивним рівнем комунікації з іншомовним оточенням, яке може мати ознаки психологічної протидії; тривалою емоційною напруженістю, відчуттям невпевненості у рівні своєї ІМК; підвищеною відповідальністю за результати професійної діяльності; професійною напруженістю, пов'язаною 3 інтенсивною іншомовною активністю та необхідністю аналізу великих обсягів іншомовної інформації. Це свідчить про те, що до їхньої діяльності висуваються нетривіальні професійні, психологічні та психофізіологічні вимоги, де закономірним наслідком стресорів є зниження продуктивності професійної діяльності та порушення психологічного та соматичного здоров'я. Хоча IMК на заняттях формується в умовах психологічного комфорту, проведений нами аналіз причин неефективної навчальної діяльності майбутніх МВУМВ, а в подальшому і професійної, свідчить про те, що більшість з них пов'язана безпосередньо 3 впливом стресорів на їх функціональні стани. Крім того, навчання в спеціальних немовних закладах вищої освіти характеризується певним рівнем нервово-психічної напруженості, тривожності, емоційним та інформаційним стресом та іншими етимологічними чинниками, дія яких частіше за все призводить до перенапруження й астенізації адаптаційних механізмів, виснаження функціональних резервів організму майбутнього MВУМВ та зниження його працездатності. Усе це спричиняє появу у навчаємих різних патологічних синдромів, серед яких найбільш поширені психофізіологічні порушення функціональних станів, що негативно позначається на формуванні супремального рівня IМК та стресостійкості. Це у свою чергу потребує застосування технології інтегрованого навчання, оскільки супремальний рівень ІМК передбачає вільне оперування іншомовними ресурсами, реалізацію комунікативних намірів, розвиток професійних умінь і навичок працювати із спеціальними та відкритими іншомовними джерелами, додатковою інформацією тощо у поєднанні не лише 3 необхідним рівнем розвитку професійно важливих якостей, а й із здатністю до саморегуляції та самоконтролю. Тому необхідним є додаткове вивчення психофізіологічних особливостей майбутніх МВУМВ та врахування їх під час СІмП.

Проблема профілактики та запобігання дезадаптивних станів у майбутніх МВУМВ, що викликані стресорами, значно виходить за межі фізіологічної емпірії i пов'язана 3 формуванням i розвитком у них адаптивних механізмів довільної та мимовільної психофізіологічної саморегуляції, розвитком такої базальної властивості особистості, як адаптивність, формуванням валеогенної мотивації та валеогених 
властивостей. Зокрема це підтвердило проведене експертне опитування діючих МВУМВ з подальшою квантифікацією даних, яке засвідчило, що при виконанні ними професійних завдань прогностичного рівня (у деяких випадках навіть репродуктивного), постають труднощі не лише технологічного чи комунікативного, а й психологічного та психофізіологічного характеру. У цьому контексті нам була цікава думка майбутніх МВУМВ щодо доцільності застосування в ході СІмП методик ПФС для підвищення їх працездатності і рівня ІМК. Для цього розробили анкету та провели опитування майбутніх МВУМВ щодо необхідності психофізіологічної саморегуляції їхніх функціональних станів під час опанування іноземними мовами. Реліабельність та валідність дослідження забезпечувалися різноплановим науково-теоретичним аналізом проблеми, відповідністю застосованих методів завданням дослідження, адекватним математичним апаратом обробки даних, достатньо репрезентативною вибіркою респондентів.

Таким чином, математично-статистична обробка отриманих результатів показала, що майже 93 \% респондентів вважає за необхідне вдосконалювати рівень ІМК у взаємозв'язку з їхньою психологічною підготовкою, а чверть що це «гарантія якісного виконання навчальних завдань під час спеціальної іншомовної підготовки». Майже п'ята частина респондентів пропонує для формування інтегративних компетенцій використовувати методики ПФС під час проведення занять з іноземних мов, а $26 \%$ - що це створює підгрунтя для їхньої подальшої ефективної психофізіологічної підготовки до дій в екстремальних умовах як складової їх професійної компетентності. Крім того, $42 \%$ респондентів вважає, що мають самостійно вміти адаптуватися до будь-яких стресових ситуацій і навіть подолати стрес, оскільки відсутність навичок ПФС негативно позначиться на рівні СІмП в контексті адаптації до виконання професійних завдань в екстремальних умовах та не сприяє подальшій практичній роботі.

Зважаючи на компонентний склад IMК i розуміння переважної більшості респондентів того, що успішність опанування ними іноземними мовами та супремальний рівень ІМК забезпечують не лише соціальна адаптація i рівень професійно важливих якостей, а й здатність до саморегуляції та самоконтролю, ми провели відбір методик ПФС для їх використання у процесі СІмП майбутніх МВУМВ. При їх відборі керувалися такими вимогами: методики ПФС мають бути ефективними, обмеженими у часі, не відволікати майбутніх МВУМВ від виконання навчальних завдань, не викликати негативних відчуттів. Однією з переваг відібраних методик $\epsilon$ те, що вони доступні кожному майбутньому MВУМВ та не потребують великих зусиль або спеціального обладнання i можуть виконуватися самостійно за умови систематичності та регулярності занять. Гарантією успіху, безумовно, є як бажання майбутніх МВУМВ здобувати іншомовні знання сучасного рівня та їх особистий інтерес до методик, що дають можливість комплексно підвищувати рівень ІМК і стресостійкості, а також 
сприяють ефективності професійної діяльності без додаткового психофізіологічного напруження, так i ознайомлення презентерів 3 методиками психологічної теорії та використання ними ії напрацювань під час занять із майбутніми МВУМВ. Визначення дієвості відібраних методик ПФС у сукупності із СІмП було апробовано на основній і контрольній групах майбутніх МВУМВ.

Нетривіальність професійної діяльності передбачає досягнення майбутніми МВУМВ супремального рівня IМК, важливими компонентами якого є наявність у них здатностей до самостійної організації вивчення мови, модернізації особистісної системи формування необхідного рівня IMК, самоконтролю i саморегуляції, а також умінь i навичок вибирати i використовувати навчально-методичні стратегії. Вищезазначене практично реалізували, використавши загальні, інноваційні і спеціальні методики ПФС, які $є$ частиною інструментарію психологічної підготовки, однією з важливих складових професійної підготовки майбутніх МВУМВ. Так, загальні методики ПФС використовували під час занять 3 іноземної мови для активізації пам'яті, покращення уваги та реакцій, зниження напруженості, усунення тремору, тривоги, невпевненості, підвищення особистісної організації. Крім того, для тренування рухливості нервових процесів використовували вправи з методик, які основані на принципах поведінкової психотерапії Джозефа Вольпе.

Серед інноваційних методичних технологій найбільш ефективним виявилося застосування такої перспективної методики ПФС, як функціональна музика («Музично-психологічний масаж», «Музичнофілософський аутотренінг», «Музично-медитативна методика саморегуляції»). Під час її прослуховування тренується рухливість нервових процесів; здійснюється подальший розвиток емоційної та когнітивної сфери; формується відповідний емоційний стан. Виконання вправ цих методик стимулює входження майбутніх МВУМВ у мовленнєву та навчальну діяльність; підтримує оптимальний рівень виконання завдань; активізує резервні можливості організму у разі виснаження внаслідок перевтоми (5-6 навчальна година); сприяє розрізненню головного і другорядного, керуванню нервово-психічною стійкістю; підвищує рівень професійної готовності та стресостійкості; стимулює уважність та спостережливість. Цю методику використовували перед заняттями, під час яких потрібні велика концентрація уваги та розумових зусиль. Також функціональна музика входить до арсеналу методик, які використовуються для емоційної ізоляції всього неконтекстуального. Але слід зазначити, що ефективними були лише нетривалі музичні сеанси (до 15 хвилин), інтервал між якими становить не менше двох годин.

Спеціальні методики ПФС, на відміну від вищезазначених, використовували під час формування супремального рівня компетентності окремих складових IМК, таких, як говоріння, читання, письмо, аудіювання. Під час підготовки майбутніх МВУМВ до говоріння ефективним виявилося 
сумісне використання вправ 3 номенклатури загальних і спеціальних методик ПФС, зокрема:

«Активна м'язова релаксація» (АМР) та подібна їй «Ізометрична гімнастика» запобігали зниженню мимовільної м'язової напруженості, що сприяло зменшенню тривожності та нервово-психічної напруженості, підвищувало концентрацію уваги і спостережливість;

«Пасивна м'язова релаксація» (ПМР) сприяла зосередженню уваги майбутніх МВУМВ на сенсорних сигналах, що надходять 3 конкретних груп м'язів, і подальшому їх розслабленню під час концентрації уваги.

Безпосередньо під час говоріння, а також читання використовували вправи методики АМР для розслаблення м'язів, що не беруть участі у цьому акті, а також контролю над тією групою м'язів, що найбільше напружуються під час виконання навчальних вправ або фахових дій в іншомовному середовищі. Дрібна моторика пов’язана 3 мовним апаратом і відповідні миттєві саморегуляційні вправи сприяли зменшенню психофізіологічного напруження, посиленню уваги та концентрації на процесі говоріння. Отже, релаксація локального м’язового напруження давала змогу майбутнім МВУМВ уникнути порушень під час говоріння та читання.

Інша справа, якщо для підготовки, наприклад, аналітичної довідки чи презентації необхідно опрацювати великий обсяг інформаційних джерел, а це потребує високої концентрації уваги, спостережливості, значного перевантаження пам'яті, активізації критичного мислення. У такому разі доцільним було використання вправ 3 номенклатури загальних методик саморегуляції, методики ПМР та іiі варіації - «Образно-прогресуюча м’язова релаксація», а під час перерви (відпочинку) - функціональної музики протягом 5-10 хвилин.

Для аудіювання методики ПФС ми підбирали відповідно до основних етапів роботи з аудіотекстом, які є загальноприйнятими в методиці вивчення іноземних мов: Pre-listening, While-listening, Post-listening етапи [4].

До прослуховування аудіотексту майбутній МВУМВ може виявитися психофізіологічно не готовим і потрапити у стан динамічної неузгодженості. Тому на дотекстовому етапі майбутнім МВУМВ пропонувалося за допомогою загальних методик ПФС увійти в стан спокою, що є свідченням їх готовності до аудіювання взагалі. Це впливало на розвиток умінь антиципації, що нівелює мовні труднощі. Крім того, вони, виконуючи певні вправи 3 номенклатури загальних методик ПФС, готуються до смислової антиципації, що у свою чергу сприяє розвитку вмінь глобального розуміння аудіотексту [4, 6].

Під час текстового етапу майбутні МВУМВ мають перебувати в стані адекватної мобілізації, якого досягали за допомогою використання спеціальних методик, зокрема методики ПМР, «формули мобілізації», «корсету впевненості» та «створення конкуруючої домінанти». Післятекстовий етап потребує інтелектуальної активності, короткочасної активізації пам'яті, суміщення різних іншомовних дій, що спричиняє 
відчуття тривоги, невпевненості і тривалу психоемоційну напруженість. У подібній критичній ситуації майбутнім МВУМВ пропонується скористатися «корсетом впевненості», сконцентруватися на диханні, зосередитися на завданні, а не на негативних відчуттях, шляхом створення «конкуруючої домінанти», а також скористатися особистою програмою психофізіологічного захисту.

Письмо як наступна складова IMК потребує значної кількості вмінь i навичок та спричиняє надмірну нервово-психічну напруженість, тремор та невпевненість у рівні своєї фахової іншомовної компетентності. Для подолання цих психогенних чинників майбутні МВУМВ використовували «Дихальні вправи», функціональну музику та «корсет впевненості» разом із релаксаційними вправами методик АМР та ПМР. За їх допомогою вони підтримували оптимальний рівень виконання письмових дій без зайвого напруження та незалежно від умов перебування.

Для ефективного застосування методик ПФС майбутні МВУМВ використовували СД-диск з аудіофайлами, який додається до розробленого методичного посібника. Аналіз результатів порівняння даних зрізу знань майбутніх МВУМВ до і після застосування методик ПФС у ході опанування іноземними мовами показав, що рівень знань в основній групі підвищився майже на 12 \% порівняно з результатами контрольної групи.

Висновок. Використання методик психофізіологічної саморегуляції функціонального стану у процесі формування у майбутніх МВУМВ супремального рівня IMК у взаємозв’язку 3 їхньою психологічною підготовкою $є$ цілком виправданим i дає змогу інтенсифікувати процес розуміння i засвоєння ними інтегративних компетенцій та творчого застосування знань під час вирішення іншомовних практичних завдань, а також сприяє створенню передумов для формування та розвитку оптимального рівня мотивації до вивчення іноземних мов. Запропоновані методики ПФС мають достатнє теоретичне підгрунтя, чіткі прагматичні стимули та реальне практичне значення для формування у майбутніх МВУМВ фахової іншомовної компетентності супремального рівня.

Перспективи подальших досліджень полягають у розробці методичних рекомендацій щодо сумісного використання номенклатури методик ПФС з методиками викладання іноземних мов.

\section{ЛІТЕРАТУРА}

1. Вікторова Л. В. Сучасні підходи та інноваційні тенденції у викладанні іноземних мов професійного спрямування. Національна академія СБУ. Педагогічні науки. 2013. № 109. C. 20-25. URL:http://enpuir.npu.edu.ua/bitstream/123456789/7508/1/V\%D1\% 96ktorova.pdf. (дата звернення 30.01.2018).

2. Загальноєвропейські рекомендації з мовної освіти: вивчення, викладання, оцінювання. URL: http://www.nbuv.gov.ua/Portal/Soc.Cum/13/redun.htm. (дата звернення 15.12.2017).

3. Ізмайлова О.А. Формування іншомовної комунікативної компетенції як структурного компоненту комунікативної культури студентів мовних ВНЗ. Викладання мов у вищих навчальних закладах освіти. 2010. № 17. С. 66-72. 
4. Крапчатова Я. А. Психолого-педагогічні передумови організації само- i взаємоконтролю рівня сформованості англомовної компетенції в аудіюванні майбутніх філологів. Вісник КНЛУ Серія: Педагогіка та психологія. 2010. Вип. 18. С. 229-239.

5. Ніколаева С. Ю. Цілі навчання іноземних мов в аспекті компетентністного підходу. Іноземні мови. 2010. №2. 267 с.

6. Одинцова Н. Б. Обучение диалогической речи на уроках французского языка. Электронный научно-практический журнал «Современная педагогика». 2017. URL: http://pedagogika.snauka.ru/ 2014/04/2265.

7. Розов В. І. Формування і розвиток механізмів адаптивної психофізіологічної саморегуляції. Проблеми вищзї иколи. 2004. № 81. С. 87-92.

8. Чиханцова О. Роль іншомовної професійної комунікаційної компетенції під час оволодіння фахом у BН3. URL: http://social-science.com.ua/article/695. (дата звернення 27.12.2017).

\section{REFERENCES}

1. Victorova, L. V. (2013). Suchasni pidhodi ta innovatsiyni tendentsiyi u vikladanni inozemnih mov profesiynogo spryamuvannya [Modern approaches and innovative trends in the teaching of foreign languages of professional orientation]. National Academy of the SBU. Pedagogical sciences, 109, 20-25. Available at : http: //enpuir.npu.edu.ua/bitstream/123456789/7508/1/V\%D1\%96ktorova.pdf (in Ukrainian).

2. Zagalnoevropeyski rekomendatsiyi $\mathrm{z}$ movnoyi osviti: vivchennya, vikladannya, otsinyuvannya [European-wide recommendations on language education: study, teaching, evaluation]. Available at : http://www.nbuv.gov.ua/Portal/Soc.Cum/13/redun.htm.

3. Izmaylova, O.A. (2010). Formuvannya inshomovnoyi komunikativnoyi kompetentsiyi yak strukturnogo komponentu komunikativnoyi kulturi studentiv movnih VNZ [Formation of foreign language communicative competence as a structural component of the communicative culture of students of language higher educational establishments]. Teaching languages in higher education institutions, 17, 66-72 (in Ukrainian).

4. Krapchatova, Ya. A. (2010). Psihologo-pedagogichni peredumovi organizatsiyi samoi vzaemokontrolyu rivnya sformovanosti anglomovnoyi kompetentsiyi v audiyuvanni maybutnih filologiv [Psychological and pedagogical prerequisites for self-organization and control of the level of formation of English competence in listening to future philologists]. Bulletin of KNLU Series: Pedagogy and Psychology, 18, 229-239 (in Ukrainian).

5. Nikolaeva, S. Yu. (2010). Tsili navchannya inozemnih mov $v$ aspekti kompetentnistnogo pidhodu [Objectives of teaching foreign languages in terms of competency approach]. Foreign languages, 2, 267 pp. (in Ukrainian).

6. Odintsova, N. B. (2017). Obuchenie dialogicheskoy rechi na urokah frantsuzskogo yazyika [Teaching Dialogue Speech at French Lessons]. Electronic scientific journal «Modern pedagogy». Available at : http://pedagogika.snauka.ru/ 2014/04/2265. (in Ukrainian).

7. Rozov, V. I. (2004). Formuvannya i rozvitok mehanizmiv adaptivnoyi psihofiziologichnoyi samoregulyatsiyi [Formation and development of mechanisms of adaptive psycho-physiological self-regulation]. Problems of higher education, 81, 87-92 (in Ukrainian).

8. Chikhantsova, O. Rol inshomovnoyi profesiynoyi komunikatsiynoyi kompetentsiyi pid chas ovolodinnya fahom $\mathrm{u}$ VNZ [The role of foreign-language professional communication competence when acquiring a specialty in higher education]. Available at : http://socialscience.com.ua/article/695 (in Ukrainian). 


\title{
РЕЗЮМЕ
}

Нина Лавриненко, кандидат физико-математических наук, доцент

Светлана Лысенко, кандидат педагогических наук Военно-дипломатическая академия имени Евгения Березняка

\section{Инновационный подход к специальной иноязычной подготовке магистров военного управления в международных отношениях}

Рассмотрен один из способов формирования интегративных компетенций, который заключается в сочетании методик психофизиологической саморегуляции функииональных состояний будущчих магистров военного управления в международных отношениях с методиками иноязычной и профессиональной подготовки. Составлено и апробировано номенклатуру общих, инновационных и специиальных методик психофизиологической саморегулящии функциональных состояний будущих магистров военного управления в международных отношениях. Интенсифисцировано процесс понимания и усвоения будущими магистрами военного управления в международных отнотениях интегративных компетенций, а также созданы предпосылки для формирования и развития оптимального уровня мотиваџии изучения иностранных языков.

Ключевые слова: специальная иноязычная подготовка; инновачионный подход; интегративные компетенции; технологии интегрированного обучения; психофизиологическая саморегулячии; магистр военного управления в международных отночениях.

\section{SUMMARY}

\author{
Nina Lavrynenko, \\ Candidate of Physical and Mathematical Sciences, associate professor, \\ Svetlana Lysenko, \\ Candidate of Pedagogical Sciences \\ Military Diplomatic Academy named after Yevgeny Berezniak
}

\section{Innovative approach to the specific foreign-language training of masters of military management in international relations}

Introduction. The priority component of Ukraine's educational policy is the transitivity of the existing model of training specialists with supremum levels of foreign language competence (FLC) in conjunction with the high level of psycho-physiological self-regulation of the functional state (PFS).

Purpose. The purpose of the article is to substantiate the effectiveness of pedagogical and psychological technologies for intensifying the process of foreign language (FL) study, taking into account the professional activity conditions of the masters of military management in international relations (MMMIR) and modern integration processes.

Methods. The following basic methods are used: theoretical analysis, synthesis, modeling; questioning, testing, self-evaluation; expert assessments and mathematical statistics.

Results. Based on the component composition of the professional FLC and the main factors that characterize the professional activities of the MMMIR, we conducted a selection and testing of PFS techniques in order to use them in the process of future MMMIR specific FL training. The consistent use of the nomenclature of these methods with the methods of teaching 
FL has made it possible to intensify the process of understanding and digestion of integrated competencies by future MMMIR, as shown by a comparative analysis of the assessment of their knowledge (the results of knowledge assessment increased by almost 12\%).

Originality. The nomenclature of general, innovative and special methods of PFS has been substantiated and tested, interdisciplinary connections have been established, which allowed the formation of the future MMMIR's FLC supremum level and the necessary level of stress resistance.

Conclusion. The use of PFS techniques in the process of formation of the future MMMIR's FLC supremum level in conjunction with their psychological training is fully justified. The proposed PFS methods have a sufficient theoretical background and practical value for the formation of the future MMMIR's FLC supremum level. Research perspectives are to develop methodological recommendations for the joint use of the nomenclature of PFS methods with the methods of teaching $F L$.

Key words: specific foreign language training; innovative approach; integrative competences; integrated training technologies; psycho-physiological self-regulation; master of military management in international relations. 